\title{
Influence of doses and methods of entering of nitrogen fertilizers on yield and quality of winter wheat grain
}

\author{
R. Ivanina \\ Institute of Bioenergy Crops and Sugar Beet of NAAS \\ 25 Klinichna Str., Kyiv, 03141, Ukraine \\ e-mail: v_ivanina@meta.ua
}

Goal. To achieve high yield and quality of winter wheat grain of domestic variety Yasochka by optimizing forms, doses, timing, and methods of application of nitrogen fertilizers. Methods. Short-term field and analytical. Results. The data of research in the effectiveness of nitrogen fertilizers under winter wheat and their influence on yield and quality of grain of the culture. It is determined that the spring timing of the application of nitrogen fertilizers compared to entering them for plowing $\left(\mathrm{N}_{60} \mathrm{P}_{60} \mathrm{~K}_{60}\right)$ significantly increased the yield of winter wheat. At the dose of nitrogen $\mathrm{N} 60$ entered in frozen-thawed soil (leached chernozem) compared to entering the same dose for tillage, grain yield of winter wheat increased on average on 0.47 t/ha over the 2017 - 2019. The most effective was 3-times application of nitrogen fertilizers in spring in the dose of $90 \mathrm{~kg} / \mathrm{ha}$ on the background of P60K60 for plowing. The approach of terms of the application of nitrogen fertilizers to the stages of the formation of productive stalks and the accumulation of protein in the grain of winter wheat provided the highest return from fertilizer use. Foliar feeding of crops with micronutrient Maksimus increased the yield and did not affect significantly grain quality of winter wheat. Conclusions. The greatest impact from the application of nitrogen fertilizers in sowings of winter wheat of variety Yasochka was gained at entering $\mathrm{N}_{30}$ in frozen-thawed soil $+\mathrm{N}_{30}$ in the phase of the tube along with micronutrient Maksimus $+\mathrm{N}_{30}$ in the phase of flag leaf: grain yield $-6.85 \mathrm{t} / \mathrm{ha}$, exceeding the control without fertilizer - on $1.77 \mathrm{t} / \mathrm{ha}$. The increase of the dose of nitrogen fertilizer from 90 to $120 \mathrm{~kg} / \mathrm{ha}$ resulted only in a trend of increasing yield. The highest grain quality of winter wheat was obtained at a nitrogen dose of $90 \mathrm{~kg} / \mathrm{ha}$ with its 3-times entering in the spring: the protein content in the grain - 12.4-12.5\% (exceeds the control without fertilizers on $0.9-1 \%$ ). The quality of winter wheat grain was dependent on the dose of nitrogen fertilizer and foliar feeding with carbamide in the later stages of organogenesis.

Key words: soil, tillage, foliar feeding, accumulation of proteins.

DOI: https://doi.org/10.31073/agrovisnyk202004-12

Nitrogen nutrition is one of the determinants of improving crop productivity. In the period of acute shortage of organic fertilizers, minimization of legumes in crop rotation, the absence of perennial legumes in them, the traditional practice of agricultural production is violated, its sensitivity to the impact of abnormal climatic phenomena is increased, productivity is reduced [1-4]. Under these conditions, a set of technological measures aimed at optimizing nitrogen nutrition becomes one of the key elements of the sustainability and high productivity of agriculture [5,6].

Winter wheat is acutely responsive to the shortage and excess of nitrogen fertilizers. Due to nitrogen deficiency, the yield and quality of winter wheat grain decreases, the excess of nitrogen causes laying down of crops, increases grain loss during harvesting, which ultimately leads to a decrease in productivity [7,8].

Optimizing the forms, doses, ways and terms for applying nitrogen fertilizers are the traditional agrochemical measures that can solve this problem. However, their effectiveness depends on the varietal characteristics of winter wheat, the availability of plants with nutrients in the most critical periods of growth and development, involvement in the fertilizer system of micro fertilizers and growth regulators. In modern agriculture, high yield of winter wheat is the result of optimization of agrochemical measures in varietal agricultural technology of this crop cultivation [9-11].

The aim of our research was to achieve high yields and quality of grain of domestic winter wheat "Yasochka" by optimizing the forms, doses, terms and ways of nitrogen fertilizers application.

Materials and research methods. The studies were conducted in a temporary field experiment at the Bila Tserkva Research-Breeding Station. The drilling area is $33 \mathrm{~m}^{2}$, the accounting area $-25 \mathrm{~m}^{2}$. The placement of variants in experiments is systematic sequential, follows four times repetition.

Soil of the experimental field - leached black soil, medium-loam, which has the following agrochemical and physical-chemical characteristics of the arable $(0-30 \mathrm{~cm})$ layer: hydrolytic acid by Kappen according to GOST 26212-91-1.71-1.80 cmol/kg of soil; the total humus content by Turin according to DSTU 4289:2004 3.6-3.8\%; mobile phosphorus and potassium by Chirikov according to DSTU 4115-2002 - 153-170 and 64$78 \mathrm{mg} / \mathrm{kg}$ of soil, respectively; alkaline hydrolyzed nitrogen by Cornfield according to DSTU4729:2007 - 110$115 \mathrm{mg} / \mathrm{kg}$ of soil.

Wheat winter variety - "Yasochka". Growing agrotechnology is generally accepted in this area. Phosphorous and potassium fertilizers were applied under deep plowing in the form of simple granular super-phosphate and potassium chloride; nitrogen - for core fertilization, top-dressing and foliar. For the 
plowing and in spring on the frozen ground, ammonium nitrate was applied by spreading it over the surface of the plot. In the phase of tube entry and appearance of the flag leaf, winter wheat was sprayed with $10 \%$ urea solution. In variants which predict adding microfertilizers into the urea solution, chelate microfertilizer "Maximus" at a dose of $4 \mathrm{~kg} / \mathrm{ha}$ was used.

"Maximus" microfertilizer manufactured by "Ekoplon SA" Poland was characterized by high water solubility, water $\mathrm{pH}-6.5-7.2$, containing $\mathrm{N}-20 \%, \mathrm{P}-20 \%, \mathrm{~K}-20 \%, \mathrm{~B}-0.051 \%$, $\mathrm{Cu}-0.060 \%, \mathrm{Fe}-$ $0.11 \%, \mathrm{Mn}-0.013 \%, \mathrm{Zn}-0.04 \%$, Mo $-0.0012 \%$.

Harvesting of winter wheat was carried out with test bundles, followed by weighing and conversion to 1 ha. The protein content in winter wheat grain was determined by Barnstein; total nitrogen was transferred for protein by coefficient - according to DSTU 3768-2004. The study results were analyzed using the method of variance and correlation analysis.

Study results and discussion. The results of the studies showed that the application of complete mineral fertilizer for winter wheat $\left(\mathrm{N}_{60-90} \mathrm{P}_{60} \mathrm{~K}_{60}\right)$ increased its yield compared to the control without fertilizer by 0.86-1.86 t/ha; only phosphorus and potassium - by $0.2 \mathrm{t} / \mathrm{ha}$. Due to nitrogen fertilizers, the yield of winter wheat increased by $0.66-1.66 \mathrm{t} / \mathrm{ha}$, which significantly exceeded the efficiency of the phosphorus-potassium fond (table).

Especially effective was the use of nitrogen fertilizers in the spring. Compared to the application of complete fertilizer for plowing $\left(\mathrm{N}_{60} \mathrm{P}_{60} \mathrm{~K}_{60}\right)$, nitrogen applied on frozen ground in the spring at a dose of $\mathrm{N}_{60}$ against the fond of $\mathrm{P}_{60} \mathrm{~K}_{60}$ increased the yield of winter on $0.47 \mathrm{t} / \mathrm{ha}$ wheat an average for 2017-2019. The use of nitrogen fertilizers at the beginning of spring tillering of winter wheat ensured the formation of its productive stalks.

The application of $60 \mathrm{~kg} / \mathrm{ha}$ of nitrogen in two lines in the spring $\left(\mathrm{N}_{30}\right.$ permafrost $+\mathrm{N}_{30}$ outlet into the tube) had no significant advantages compared to its single application at permafrost period - grain yield was $6.44 \mathrm{t} / \mathrm{ha}$. Extra feeding of Maximus microfertilizers, $4 \mathrm{~kg} / \mathrm{ha}$ in the tube phase of winter wheat on the fond of twice applying nitrogen fertilizers, increased grain yield by $0.19 \mathrm{t} / \mathrm{ha}$ at an absolute yield rate of $6.63 \mathrm{t} / \mathrm{ha}$, indicating a trend of productivity growth.

Winter wheat yield depending on fertilization system, BTRBS, $t /$ ha

\begin{tabular}{|c|c|c|c|c|c|c|}
\hline \multirow[t]{2}{*}{$\begin{array}{l}\text { № } \\
\text { var. }\end{array}$} & \multirow[t]{2}{*}{ Variant } & \multicolumn{3}{|c|}{$\begin{array}{c}\text { Grain yield, } \\
\text { t/ha }\end{array}$} & \multirow{2}{*}{$\begin{array}{c}\text { Average } \\
\text { for } 2017- \\
2019, \\
\text { t/ha }\end{array}$} & \multirow{2}{*}{$\begin{array}{c}\text { Straw yield } \\
\text { for } 2017- \\
2019, \\
\text { t/ha }\end{array}$} \\
\hline & & 2017 & 2018 & 2019 & & \\
\hline 1 & Without fertilizers (control) & 4,21 & 5,86 & 5,16 & 5,08 & 6,6 \\
\hline 2 & $\mathrm{P}_{60} \mathrm{~K}_{60}-\Phi \mathrm{OH}$ & 4,43 & 6,13 & 5,27 & 5,28 & 6,9 \\
\hline 3 & $\mathrm{~N}_{60} \mathrm{P}_{60} \mathrm{~K}_{60}-$ under plowing & 4,67 & 7,14 & 6,02 & 5,94 & 8,3 \\
\hline 4 & $\Phi \mathrm{OH}+\mathrm{N}_{60}-$ in spring & 4,79 & 7,37 & 7,07 & 6,41 & 8,8 \\
\hline 5 & $\Phi \mathrm{OH}+\mathrm{N}_{30}+{ }^{*} \mathrm{~N}_{30}$ & 4,82 & 7,40 & 7,10 & 6,44 & 8,8 \\
\hline 6 & $\Phi \mathrm{OH}+\mathrm{N}_{30}+{ }^{*} \mathrm{~N}_{30 \mathrm{M}}$ & 4,88 & 7,70 & 7,31 & 6,63 & 9,1 \\
\hline 7 & $\Phi \mathrm{OH}+\mathrm{N}_{30}+{ }^{*} \mathrm{~N}_{30}+{ }^{* *} \mathrm{~N}_{30}$ & 4,85 & 7,67 & 7,45 & 6,66 & 9,3 \\
\hline 8 & $\Phi \mathrm{OH}+\mathrm{N}_{30}+{ }^{*} \mathrm{~N}_{30 \mathrm{M}}+{ }^{* *} \mathrm{~N}_{30}$ & 4,92 & 7,92 & 7,72 & 6,85 & 9,5 \\
\hline 9 & $\Phi \mathrm{OH}+\mathrm{N}_{60}+{ }^{*} \mathrm{~N}_{30}+{ }^{* *} \mathrm{~N}_{30}$ & 4,95 & 8,02 & 7,70 & 6,89 & 9,6 \\
\hline 10 & ФOH $+\mathrm{N}_{60}+{ }^{*} \mathrm{~N}_{30 \mathrm{M}}+{ }^{* *} \mathrm{~N}_{30}$ & 4,97 & 8,11 & 7,74 & 6,94 & 9,7 \\
\hline & $\mathrm{HIP}_{05}$ & 0,29 & 0,40 & 0,33 & 0,36 & 0,4 \\
\hline & $\mathrm{P}, \%$ & 2,6 & 3,0 & 3,3 & 2,9 & 3,7 \\
\hline
\end{tabular}

Note: $\mathrm{N}_{30-60}$ - in spring on frozen ground; ${ }^{*} \mathrm{~N}_{30}$ - beginning of the tube exit ( ${ }^{*} \mathrm{~N}_{30} \mathrm{M}$ - with microfertilizer); ${ }^{* *} \mathrm{~N}_{30}$ - flag leaf appears.

The highest yield of winter wheat grain was achieved at nitrogen doses of $90 \mathrm{~kg} / \mathrm{ha}$ with three time fertilization in the spring combined with the Maximus microfertilizer. With the application of $\mathrm{N}_{30}$ on frozen soil $+N_{30}$ combined with Maximus at the tube exit phase $+N_{30}$ at flag leaf phase the yield of grain was 6.85 t/ha with excess to the control without fertilizers - on $1.77 \mathrm{t} / \mathrm{ha}$. Increasing the dose of nitrogen fertilizers to 120 $\mathrm{kg} / \mathrm{ha}$ according to over mentioned the algorithm of their application provided only the tendency of grain yield increase on $0.09 \mathrm{t} / \mathrm{ha}$, which is not economically efficient.

The spring timing of nitrogen fertilizer contributed to the accumulation of protein in winter wheat grain and improved its quality. Thus, in the control without fertilizers, the protein content of winter wheat grain was $11.5 \%$; for the application of $\mathrm{N}_{60}$ on frozen ground $-12.1 \% ; \mathrm{N}_{30}$ on frozen ground $+\mathrm{N}_{30}$ at the tube exit phase - $12 \%$; twice application in spring combined with Maximus - $12.1 \%$. Due to nitrogen fertilizers $(60 \mathrm{~kg} / \mathrm{ha})$ applied both at the period of spring vegetation recovery and the plants exit into tube, the protein content in winter wheat grain increased by $0.5-0.6 \%$, microfertilizers "Maximus" did not effect on grain quality (fig.). 


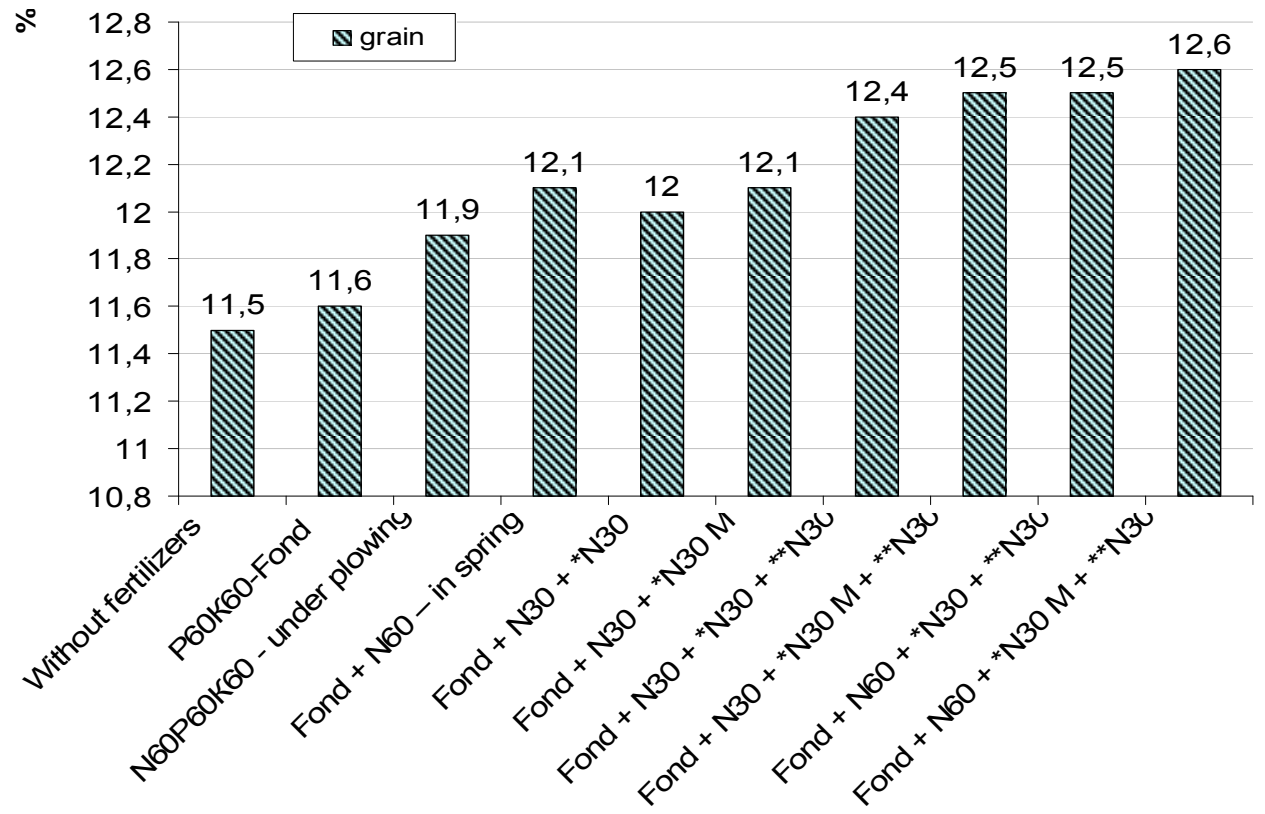

\footnotetext{
Protein content in winter wheat grain depending on fertilization system, BTRBS, average 20172019, \%
}

Particularly effective in improving the quality of winter wheat grain is the foliar application of nitrogen fertilizers in the flag leaf phase. The treatment of winter wheat crops with urea at a dose of $N_{30}$ in the flag leaf phase on the fond of $\mathrm{N}_{30}$ on frozen ground $+\mathrm{N}_{30}$ outlet into the tube provided a protein content in winter wheat grain - 12.4-12.5\%, which is compared to one and two times the application of nitrogen fertilizers in the spring ( $60 \mathrm{~kg} / \mathrm{ha}$ dose) was determined to be higher by $0.3-0.5 \%$, to control without fertilizers - by 0.9 $1.0 \%$. Late dates of foliar feeding of winter wheat crops with a $10 \%$ urea solution significantly increased the grain protein of this crop. Increasing the dose of nitrogen fertilizers in the spring from 90 to $120 \mathrm{~kg} / \mathrm{ha}$ and the additional foliar feeding with Maximus microfertilizers did not significantly affect the protein content in winter wheat grains.

\section{Conclusions}

In the case of cultivation the national variety of winter wheat "Yasochka", three times application of nitrogen fertilizers in the spring at a dose of $90 \mathrm{~kg} / \mathrm{ha}$ on the fond of $P_{60} K_{90}$ under plowing was the most effective. With the application of $N_{30}$ on frozen soil $+N_{30}$ outlet into the tube combined with microfertilizer "Maximus" + N30 flag leaf phase the grain yield was reached -6.85 t/ha with excess to the control without fertilizers - by $1.77 \mathrm{t} / \mathrm{ha}$. Increasing the dose of nitrogen fertilizers to $120 \mathrm{~kg} / \mathrm{ha}$ caused only a tendency of yield increase and was determined to be ineffective.

The quality of winter wheat grain depended mainly on the dose of nitrogen fertilizer and foliar feeding with urea in the later stages of organogenesis. For nitrogen doses of $90 \mathrm{~kg} / \mathrm{ha}$ with three times its application in the spring, the protein content in winter wheat grains was $12.4-12.5 \%$, with an excess of $0.9-1.0 \%$ over control without fertilizers. Increasing the dose of nitrogen fertilizers to $120 \mathrm{~kg} / \mathrm{ha}$ and the use of Maximus microfertilizer did not significantly affect the quality of winter wheat grain.

\section{References}

1. Mandic, V., Krnjaja, V., Tomic, Z., Bijelic, Z., Simic, A., Muslic, D., \& Gogic, M. (2015). Nitrogen fertilizer influence on wheat yield and use efficiency under different environmental conditions. Chilean journal of agricultural research, 75(1), 92-97. doi: 10.4067/S0718-58392015000100013.

2. Babulicova, M. (2014). The influence of fertilization and crop rotationon the winter wheat production. Plant Soil Environ, 60(7), 297-302. doi: 10.17221/3/2014-pse.

3. Wozniak, A. (2019). Effect of Crop Rotation and Cereal Monoculture on the Yield and Quality of Winter Wheat Grain and on Crop Infestation with Weeds and Soil Properties. International Journal of Plant Production, 13, 177-182. doi: 10.1007/s42106-019-00044-w.

4. Martyniuk, S., Pikuła, D., \& Kozieł, M. (2019). Soil properties and productivity in two long-term crop rotations differing with respect to organic matter management on an Albic Luvisol. Sci Rep, 9, 1878. doi: 10.1038/s41598-018-37087-4.

5. Hawkesford, M. J., Araus, J.-L., Park, R., Calderini, D., Miralles, D., Shen, T., Zhang, J., \& Parry, M. A. J. (2013). Prospects of doubling global wheat yields. Food Energy Security, 2, 34-48. doi: 10.1002/fes3.15. 
6. Babulicova, M. (2016). Enhancing of Winter Wheat Productivity by the Introduction of Field Pea into Crop Rotation. Agriculture, 62(3), 101-110. doi: 10.1515/agri-2016-0011.

7. Litke, L., Gaile, Z., \& Ruža, A. (2018). Effect of nitrogen fertilization on winter wheat yield and yield quality. Agronomy Research, 16(2), 500-509. doi: 10.15159/AR.18.064.

8. Berge, M., Pikula, D., Goedhart, P. W., \& Schröder, J. J. (2016). Apparent nitrogen fertilizer replacement value of grass-clover leys and farmyard manure in an arable rotations. Soil Use Manage, 32, 919. doi: $10.1111 /$ sum. 12246.

9. Lytvynenko, M. A. (2010). Realization of genetic potential. Problems of productivity and quality of grain of modern varieties of winter wheat [Scientific-production magazine]. Seed production, 6, 1-6. [In Ukrainian].

10. Blanchet, G., Gavazov, K., Bragazza, L., \& Sinaj, S. (2016). Responses of soil properties and crop yields to different inorganic and organic amendments in a Swiss conventional farming system. Agr. Ecosyst. Environ, 230, 116-126. doi: 10.1016/j.agee.2016.05.032.

11. Efretue, A., Gooding, M., White, E., Spink, J., \& Hackett, R. (2016). Effect of nitrogen fertilizer application timing on nitrogen use efficiency and grain yield of winter wheat in Ireland. Irish Journal of Agricultural and Food Research, 55(1), 32-47. doi: 10.1515/ijafr-2016-0006. 